\title{
PENGARUH ASIMETRI INFORMASI, LEVERAGE DAN UKURAN PERUSAHAAN TERHADAP PRAKTIK MANAJEMEN LABA (STUDI PADA PERUSAHAAN MANUFAKTUR YANG TERDAFTAR DI BURSA EFEK INDONESIA)
}

\author{
Kristin Verawati Sihaloho \\ Abdonsius Sitanggang
}

\begin{abstract}
Abstrak
Penelitian ini bertujuan untuk mengetahui dan membuktikan secara empiris pengaruh asimetri informasi, leverage dan ukuran perusahaan berpengaruh terhadap praktik manajemen laba pada Perusahaan Manufaktur yang terdaftar di Bursa Efek Indonesia. Manfaat penelitian adalah menambah pengetahuan mengenai pengaruh asimetri informasi, leverage dan ukuran perusahaan berpengaruh terhadap praktik manejemen laba. Populasi penelitian adalah seluruh perusahaan manufaktur yang terdaftar di Bursa Efek Indonesia yang menerbitkan laporan keuangan tahunan periode 2011-2013 sebanyak 138 perusahaan. Sampel penelitian diambil 50 perusahaan. Data yang digunakan adalah data sekunder yang dikumpulkan melalui teknik dokumentasi. Teknik analisis data yang digunakan adalah persamaan regresi linear berganda. Berdasarkan hasil penelitian disimpulkan bahwa nilai koefisien korelasi (R) sebesar 0,586. Artinya, asimetri informasi, leverage dan ukuran perusahaan mempunyai hubungan positif terhadap praktik manajemen laba pada perusahaan manufaktur yang terdaftar di Bursa Efek Indonesia. Nilai koefisien determinan ( $R$ Square) sebesar 0,344. Artinya, praktik manajemen laba dapat dijelaskan oleh asimetri informasi, leverage dan ukuran perusahaan $34,4 \%$ sedangkan $65,6 \%$ dijelaskan oleh faktor lain. Dari hasil uji t, diketahui nilai $t_{\text {hitung }}(3,377)$ $>t_{\text {tabel }}(1,976)$ dengan tingkat signifikansi $0,001<0,05$, sehingga $\mathrm{H}_{0}$ ditolak. Artinya, asimetri informasi berpengaruh positif signifikan secara parsial terhadap praktik manajemen laba. Dari hasil uji $t$, diketahui nilai $t_{\text {hitung }}(5,457)>t_{\text {tabel }}(1,976)$ dengan tingkat signifikansi $0,000<0,05$, sehingga $\mathrm{H}_{0}$ ditolak. Artinya, leverage berpengaruh positif signifikan secara parsial terhadap praktik manajemen laba. Dari hasil uji t, diketahui nilai $t_{\text {hitung }}(2,808)>t_{\text {tabel }}(1,976)$ dengan tingkat signifikansi $0,006<0,05$, sehingga $\mathrm{H}_{0}$ ditolak. Artinya, ukuran perusahaan berpengaruh positif signifikan secara parsial terhadap praktik manajemen laba. Dari hasil uji F, diketahui nilai $F_{\text {hitung }}(25,514)>$ $\mathrm{F}_{\text {tabel }}(2,67)$ dengan tingkat signifikansi $0,000<0,05$, sehingga $\mathrm{H}_{0}$ ditolak. Artinya, asimetri informasi, leverage dan ukuran perusahaan berpengaruh positif signifikan secara simultan terhadap praktik manajemen laba pada perusahaan manufaktur yang terdaftar di Bursa Efek Indonesia. Persamaan regresi linear berganda adalah $\mathrm{Y}=-0,101+0,001 \mathrm{X}_{1}+$ $0,002 \mathrm{X}_{2}+0,013 \mathrm{X}_{3}$. Artinya, asimetri informasi, leverage dan ukuran perusahaan berpengaruh positif terhadap praktik manajemen laba pada perusahaan manufaktur yang terdaftar di Bursa Efek Indonesia. Hal ini dapat dilihat dari nilai koefisien regresinya.
\end{abstract}

Kata Kunci: Asimetri Informasi, Leverage, Ukuran Perusahaan dan Manajemen Laba 


\section{PENDAHULUAN}

Menurut Scott (2009), "manajemen laba merupakan keputusan manajer untuk memilih kebijakan akuntansi tertentu yang dianggap bisa mencapai tujuan yang diinginkan, baik untuk meningkatkan laba maupun mengurangi kerugian yang dilaporkan". Adanya fenomena laba mengakibatkan pengungkapan yang menyesatkan, sehingga akan mengakibatkan terjadinya kesalahan pengambilan keputusan oleh pihak yang berkepentingan dengan perusahaan. Tujuan yang akan dicapai oleh manajemen melalui manajemen laba meliputi mendapatkan bonus dan kompensasi lainnya, mempengaruhi keputusan pelaku pasar modal, menghindari pelanggaran perjanjian utang dan menghindari biaya politik.

Pengukuran manaejmen laba dilakukan dengan menggunakan proxy Discretionary Accrual (DA) dan dihitung dengan The Modified Jones Model.

Discretionary Accrual adalah komponen aktual yang terdapat dalam kebijakan manajemen, artinya manajer dapat memberikan intervensi dalam laporan keuangan. Menurut Jensen dan Meckling dalam Rahmawati dkk., (2006), hubungan keagenan merupakan sebuah kontak yang terjadi antara manajer (agent) dengan pemilik perusahaan (principal). Wewenang dan tanggung jawab agent maupun prinsipal diatur dalam kontrak kerja atas persetujuan bersama.

Keberadaan asimetri informasi dianggap sebagai penyebab manajemen laba. Semakin banyak informasi mengenai internal perusahaan yang dimiliki oleh manajer dari pada pemegang saham, maka manajer akan lebih banyak mempunyai kesempatan untuk melakukan manajemen laba. Hasil penelitian Wiryadi dan Sebrina (2012), menyimpulkan bahwa asimetri informasi berpengaruh positif terhadap praktik manajemen laba. Hasil penelitian Muliati (2011), menyimpulkan bahwa asimetri informasi berpengaruh positif terhadap praktik manajemen laba di perusahaan perbankan yang terdaftar di bursa efek indonesia.

Perusahaan yang membiayai kegiatan operasionalnya dengan modal pinjaman akan menanggung beban tetap dengan alasan terbatasnya modal sendiri. Penerapan kebijakan leverage keuangan akan meningkatkan nilai hutang perusahaan, berarti perusahaan harus menanggung biaya modal dan resiko finansial yang lebih tinggi. Hutang semakin besar, karena perusahaan selain harus membayar pinjaman pokok, juga harus membayar bunga pinjaman rutin sampai hutang tersebut terlunaskan.

Leverage diukur dari debt ratio, yaitu total hutang dibagi total aktiva. Kenaikan leverage terjadi karena perusahaan menambah hutang untuk 
melakukan investasi dalam aktiva tetap, sehingga beban tetap yang ditanggung perusahaan semakin tinggi. Untuk mencapai tujuan tersebut mendorong manajer untuk mempraktikan manajemen laba. Dengan demikian, leverage berpengaruh positif terhadap praktik manajemen laba. Penelitian terdahulu menyebutkan bahwa leverage berpengaruh negatif dan signifikan terhadap manajemen laba (Wardani dan Warsoda, 2011).

Ukuran perusahaan (size) merupakan variabel yang mempunyai hubungan dengan manajemen laba. Ukuran perusahaan adalah suatu skala dimana dapat diklasifikasikan besar dan kecilnya perusahaan dengan berbagai cara, antara lain total aktiva, log size, nilai pasar saham. Menurut Agusti dan Paramesti (2014), perusahaan besar cenderung akan memerlukan dana yang lebih besar dibandingkan dengan perusahaan yang lebih kecil. Perusahaan yang memiliki total aktiva dengan jumlah besar atau disebut dengan perusahaan besar akan lebih banyak mendapatkan perhatian dari investor, kreditor maupun para pemakai informasi keuangan lainnya dibandingkan dengan perusahaan kecil, hal ini cenderung menimbulkan terjadinya praktik manajemen laba.

\section{Identifikasi Masalah}

Berdasarkan latar belakang perlu dilakukan penelitian mengenai pengaruh asimetri informasi, leverage, dan ukuran perusahaan terhadap praktik manajemen laba. Untuk membuktikan masalah yang muncul, sampel penelitian ini adalah perusahaan manufaktur yang terdaftar di Bursa Efek Indonesia (BEI). Alasan peneliti memilih sampel perusahaan manufaktur karena penelitian sebelumnya menggunakan perusahaan perbankan yang hampir serupa, walaupun ada peneliti sebelumnya yang meneliti perusahaan manufaktur tetapi sampelnya masih terbatas 20 perusahaan. Peneliti ingin membuktikan apakah mempunyai hasil yang berbeda dengan perusahaan manufaktur yang terdaftar di Bursa Efek Indonesia dari tahun 2011-2013 dan tidak meneliti dewan komisaris, kualitas audit, dan kepemilikan manajerial.

\section{Perumusan Masalah}

Berdasarkan identifikasi masalah, dapat dirumuskan masalah penelitian dalam bentuk pertanyaan adalah "Apakah asimetri informasi, leverage dan ukuran perusahaan berpengaruh terhadap praktik manajemen laba pada Perusahaan Manufaktur yang terdaftar di Bursa Efek Indonesia tahun 2011-2013?'”. 


\section{TINJAUAN PUSTAKA}

Menurut Sjahrial (2007:234), “agency cost atau biaya keagenan adalah biaya yang timbul karena perusahaan menggunakan utang dan melibatkan hubungan antara pemilik perusahaan (pemegang saham) dan kreditor". Biaya keagenen ini muncul dari problem keagenan. Jika perusahaan menggunakan utang, ada kemungkinan pemilik perusahaan melakukan tindakan yang merugikan kreditor. Misalnya, perusahaan melakukan investasi pada proyek-proyek yang berisiko tinggi. Karena kreditor menerima keuntungan tetap (bunga utang) berapapun keuntungan perusahaan. Ini tidak sesuai dengan konsep jika risiko bertambah, maka keuntungan juga bertambah. Untuk menghindari kerugian semacam ini, biasanya kreditor melindungi diri dengan perjanjian-perjanjian pada saat penandatanganan pemberian kredit (covenant). Covenant ini merupakan klausul dalam perjanjian kredit yang mengurangi kebebasan perusahaan dalam membuat keputusan.

\section{Manajemen Laba}

Manajemen laba dalam artian sempit ini didefinisikan sebagai perilaku manajer untuk "bermain" dengan komponen discretionary accruals dalam menentukan besarnya laba. Dalam definisi luas manajemen laba merupakan tindakan manajer untuk meningkatkan (mengurangi laba yang) dilaporkan saat ini atas suatu unit dimana manajer bertanggungjawab, tanpa mengakibatkan peningkatan atau penurunan profitabilitas ekonomi jangka panjang. Penggunaan pengukuran dasar akrual sangat penting untuk diperhatikan dalam mendeteksi ada tidaknya manajemen laba dalam perusahaan. Total akrual adalah selisih antara laba dan arus kas yang berasal dari aktivitas operasi. Total akrual dapat dibebankan menjadi dua bagian yaitu: (1) bagian akrual yang memang sewajarnya ada dalam proses penyusunan laporan keuangan, disebut normal accruals atau non discretionary accruals, dan (2) bagian yang merupakan manipulasi data akuntansi yang disebut dengan abnormal accruals atau discretionary accruals.

Menurut Stice, dkk., (2009:360), ada empat alasan yang memotivasi para manajer melakukan manajemen laba yaitu:

1. Usaha untuk memenuhi target internal

2. Memenuhi harapan eksternal

3. Melakukan perataan laba (income smoothing) yang dilaporkan 
Mempercantik laporan keuangan sebelum suatu penawaran saham perdana atau pengajuan pinja. Menurut Stice, dkk., (2009:366), langkah tersebut meliputi:

a. Pengaitan secara strategis

b. Perubahan pada metode atau estimasi dengan pengungkapan penuh

c. Perubahan dalam metode atau estimasi dengan pengungkapan yang minimal atau tanpa pengungkapan sama sekali.

d. Akuntansi non GAAP (General Accepted Principle of Accounting)

e. Transaksi fiktif

Earnings management merupakan hasil akuntansi akrual yang paling bermasalah. Penggunaan penilaian dan estimasi dalam akuntansi akrual mengizinkan manajer untuk menggunakan informasi di dalam perusahaan dan pengalaman mereka untuk menambah kegunaan angka akuntansi. Namun beberapa manajer menggunakan kebebasan ini untuk mengubah angka akuntansi terutama laba untuk kepentingan pribadi, sehingga mengurangi kualitasnya. Manajemen laba terjadi karena beberapa alasan seperti untuk meningkatkan kompensasi, menghindari persyaratan hutang, memenuhi ramalan analisis dan mempengaruhi harga saham.

Menurut Scott dalam Muliati (2011), pola manajemen laba dapat dilakukan dengan cara:

1. Taking a Bath.

2. Income Minimization

3. Income Maximization

4. Income Smoothing

Asimetri Informasi

Asimetri informasi sebagai situasi yang terbentuk karena principal (pemegang saham) tidak memiliki informasi yang cukup mengenai kinerja keuangan agent (manajer), sehingga prinsipal tidak pernah dapat menentukan kontribusi usaha-usaha agent terhadap hasil-hasil perusahaan sesungguhnya.

Scott (2009), menyatakan bahwa terdapat dua macam asimetri informasi, yaitu:

a. Adverse selection

Adverse selection yaitu bahwa para manajer serta orang-orang dalam lainnya biasanya mengetahui lebih banyak tentang keadaan dan prospek perusahaan dibandingkan dengan pihak luar. 
b. Moral Hazard

Moral hazard yaitu bahwa kegiatan yang dilakukan oleh seorang manajer tidak seluruhnya diketahui oleh investor (pemegang saham dan kreditor), sehingga manajer dapat melakukan tindakan di luar pengetahuan pemegang saham yang melanggar kontrak yang sebenarnya secara etika atau norma mungkin tidak layak dilakukan.

Perbedaan antara harga bid dan harga ask adalah spread. Jadi, bid ask spread merupakan selisih harga beli tertinggi bagi broker atau dealer bersedia untuk membeli suatu saham dan harga jual di mana broker/dealer bersedia untuk menjual saham tersebut (Restuwulan, 2013).

Pembahasan lebih lanjut mengenai spread dikemukakan oleh Cohen, dkk., dalam Muliati (2011) menyatakan bahwa riset mengenai kos transaksi/kos kesegaran (immediacy cost) harus membedakan antara spread dealer dan spread pasar. Spread dealer untuk suatu saham merupakan perbedaan harga bid dan ask yang ditentukan oleh dealer secara individual, ketika dealer hendak memperdagangkan saham tersebut, sedangkan spread pasar untuk suatu saham merupakan perbedaan harga bid tertinggi dan ask terendah diantara beberapa dealer yang sama-sama melakukan transaksi untuk saham tersebut. Berdasarkan perbedaan tersebut, maka spread pasar dapat lebih kecil dibanding Menurut Siregar (2008), pengukuran asimetri informasi dihitung dengan menggunakan relative bid-ask spread yang dioperasionalkan, sebagai berikut:

SPREAD $_{\mathrm{it}}=\left(\mathrm{Ask}_{\mathrm{it}}-\mathrm{Bid}_{\mathrm{it}}\right) /\left\{\left(\mathrm{Ask}_{\mathrm{it}}+\mathrm{Bid}_{\mathrm{it}}\right) / 2\right\} \times 100 \%$

Keterangan:

BIDASK $_{\text {it }}=$ Bid-ask spread

$\mathrm{Ask}_{\mathrm{it}}=$ Harga ask tertinggi saham perusahaan i pada tahun $\mathrm{t}$

Bid $_{\text {it }}=$ Harga bid terendah saham perusahaan i pada tahun $\mathrm{t}$ kan dengan spread dealer.

\section{Leverage Keuangan}

Menurut Sawir (2005:13), leverage diukur dari debt ratio merupakan rasio hutang yang digunakan untuk mengukur perbandingan antara total hutang dengan total aktiva atau dengan rumus:

$$
\text { Debt ratio }=\frac{\text { Total debt }}{\text { Total assets }} \times 100 \%
$$

Rasio ini memperlihatkan proporsi antara kewajiban yang dimiliki dan seluruh kekayaan yang dimiliki perusahaan. Semakin tinggi hasil persentasenya, cenderung semakin besar risiko keuangannya bagi kreditor 
maupun pemegang saham. Dari hasil pengukuran, apabila rasionya tinggi, artinya pendanaan dengan utang semakin banyak, maka semakin sulit bagi perusahaan untuk memperoleh tambahan pinjaman karena dikhawatirkan perusahaan tidak mampu menutupi hutang-hutangnya dengan aktiva yang dimilikinya. Demikian pula apabila rasio rendah, semakin kecil perusahaan dibiayai dengan hutang.

\section{Ukuran Perusahaan}

Ukuran perusahaan adalah suatu skala di mana dapat diklasifikasikan besar dan kecilnya perusahaan dengan berbagai cara, antara lain total aktiva, $\log$ size, nilai pasar saham. Karena semakin besar total aktiva, penjualan dan kapitalisasi pasar maka semakin besar pula ukuran perusahaan, ketiga variabel tersebut digunakan untuk menentukan ukuran perusahaan karena dapat mewakili seberapa besar perusahaan).

Ukuran perusahaan diukur dari logaritma natura total aktiva, atau dengan rumus:

$$
\mathrm{SIZE}=\operatorname{Ln}(\text { Total Aktiva })
$$

\section{Kerangka Berpikir}

Kerangka berpikir dalam penelitian ini dapat digambarkan sebagai berikut:

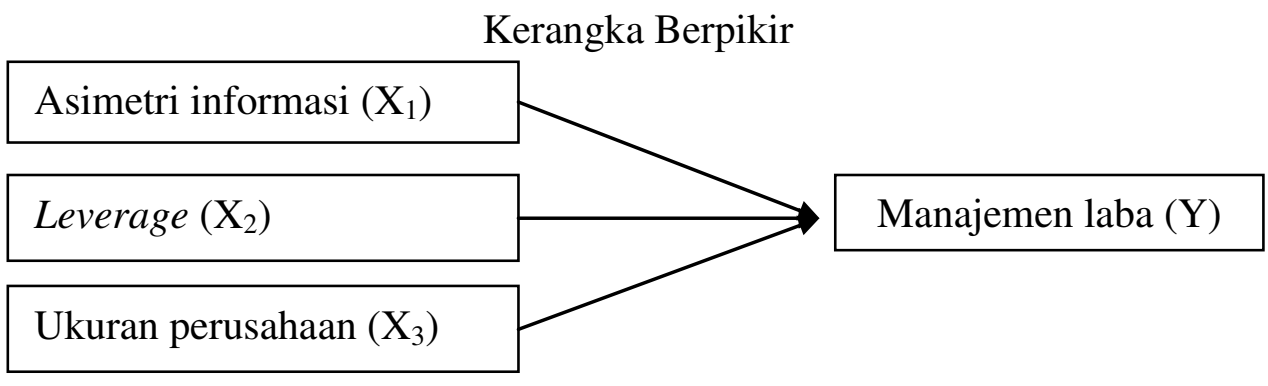

\section{Pengaruh Asimetri Informasi Terhadap Manajemen Laba.}

Salah satu informasi yang sangat penting dalam laporan keuangan adalah laba. Informasi laba merupakan komponen informasi keuangan yang menjadi pusat perhatian sekaligus dasar pengambilan keputusan pihak-pihak yang berkepentingan, misalnya digunakan untuk menilai kinerja perusahaan ataupun kinerja manajer. Oleh karena itu manajer melakukan pengelolaan terhadap angka laba (earning management). Keberadaan asimetri informasi dianggap sebagai penyebab manajemen laba. Semakin banyak informasi mengenai internal perusahaan yang 
dimiliki oleh manajer dari pada pemegang saham, maka manajer akan lebih banyak mempunyai kesempatan untuk melakukan manajemen laba (Wiryadi dan Sebrina, 2013). Dengan demikian, terdapat pengaruh positif antara asimetri informasi terhadap praktik manajemen laba.

\section{Pengaruh Leverage Terhadap Manajemen Laba}

Menurut Fahmi (2013:72), leverage mengukur seberapa besar perusahaan dibiayai dengan hutang. Penggunaan hutang yang terlalu tinggi akan membahayakan perusahaan, karena perusahaan akan masuk dalam kategori extreme leverage (hutang ekstrim) yaitu perusahaan terjebak dalam tingkat hutang yang tinggi, dan sulit untuk melepaskan beban hutang tersebut. Karena itu sebaiknya perusahaan harus menyeimbangkan beberapa hutang yang layak diambil, dan dari mana sumber yang dapat dipakai untuk membayar hutang. Perusahaan yang sebagian besar modalnya memiliki tingkat leverage tinggi dapat memberikan pengaruh yang menguntungkan bagi pemilik perusahaan, ketika perusahaan memberikan kinerja yang baik, karena keuntungan yang diperoleh dapat dibagikan kepada para pemegang saham.

Leverage berpengaruh terhadap praktik manajemen laba, ketika perusahaan mempunyai rasio leverage yang tinggi, maka perusahaan cenderung akan melakukan praktik manajemen laba, karena perusahaan terancam tidak bisa memenuhi kewajibannya dengan membayar hutangnya tepat waktu. Dengan demikian, leverage dapat berpengaruh terhadap praktik manajemen laba.

Perusahaan yang berkualitas baik, nilai yang akan diterima akan di bawah nilai sebenarnya, ini terjadi apabila pihak perusahaan tidak mengkomunikasikan keadaan yang sebenarnya kepada para stakeholder. Sebelum berinvestasi tentunya para investor melihat ukuran perusahaan terdahulu. Karena semakin besar ukuran perusahaan, maka semakin besar pula nilai perusahaan tersebut yang dapat dilihat dari nilai total asetnya. Jika ukuran perusahaan semakin besar, maka manajemen laba semakin meningkat.

\section{Pengaruh Ukuran Perusahaan Terhadap Manajemen Laba}

Ukuran perusahaan yang di tentukan dari jumlah total asset yang dimiliki perusahaan. Menurut Defond dalam Agusti dan Paramesti (2014), "ukuran perusahaan berkorelasi secara positif dengan manajemen laba. Perusahan besar mempunyai insentif yang cukup besar untuk melakukan manajemen laba, karena salah satu alasannya adalah perusahaan besar 
harus mampu memenuhi ekspektasi dari investor atau pemegang sahamnya. Selain itu, semakin besar perusahaan, semakin banyak estimasi dan penilaian yang perlu diterapkan untuk tiap jenis aktivitas perusahaan yang semakin banyak.

\section{Hipotesis}

Menurut Sugiyono (2008:93), "hipotesis merupakan jawaban sementara terhadap rumusan masalah". Hipotesis dalam penelitian ini adalah:

$\mathrm{H}_{1}$ : Asimetri informasi berpengaruh terhadap praktik manajemen laba pada perusahaan manufaktur yang terdaftar di Bursa Efek Indonesia.

$\mathrm{H}_{2}$ : Leverage berpengaruh terhadap praktik manajemen laba pada perusahaan manufaktur yang terdaftar di Bursa Efek Indonesia.

$\mathrm{H}_{3}$ : Ukuran perusahaan berpengaruh terhadap praktik manajemen laba pada Perusahaan Manufaktur yang terdaftar di Bursa Efek Indonesia.

\section{METODE PENELITIAN}

Sampel yang digunakan dalam penelitian ini sebanyak 50 perusahaan dengan kriteria pengambilan sampel,yaitu dari tahun 2011-2013.

\section{Operasionalisasi Variabel}

Variabel bebas (X) terdiri dari:

a. Asimetri informasi $\left(\mathrm{X}_{1}\right)$ yaitu suatu keadaan yang muncul ketika manajer perusahan lebih mengetahui segala informasi internal dan prospek perusahaan di masa depan dibandingkan pemgang saham dan stakeholder lainnya. asimetri informasi dihitung dengan menggunakan relative bid-ask spread yang dioperasionalkan, sebagai berikut:

$$
\mathrm{SPREAD}_{\mathrm{it}}=\left(\mathrm{Ask}_{\mathrm{it}}-\mathrm{Bid}_{\mathrm{it}}\right) /\left\{\left(\mathrm{Ask}_{\mathrm{it}}+\mathrm{Bid}_{\mathrm{it}}\right) / 2\right\} \times 100 \%
$$

Keterangan:

SPREAD $_{\text {it }}=$ Bid-ask spread

$\mathrm{Ask}_{\mathrm{it}}=$ Harga penutupan ask tertinggi saham perusahaan i pada tahun $\mathrm{t}$ $\mathrm{Bid}_{\mathrm{it}}=$ Harga penutupan bid terendah saham perusahaan i pada tahun $\mathrm{t}$

b. Leverage $\left(\mathrm{X}_{2}\right)$, yaitu mengukur sejauh mana aktiva perusahaan didanai dengan hutang. Leverage diukur dari debt ratio, yaitu:

Debt ratio $=\frac{\text { Total debt }}{\text { Total assets }} \times 100 \%$

Keterangan: Total debt $=$ Total hutang, Total Asset $=$ Total aktiva

c. Ukuran perusahaan $\left(\mathrm{X}_{3}\right)$, yaitu besar kecilnya skala perusahaan yang ditunjukkan oleh total aktivanya. Ukuran perusahaan diukur dari total 
aktiva yang ditransformasikan dalam bentuk logaritma natual (ln) dengan tujuan untuk memperhalus data, sehingga diharapkan mampu mengelimisir perbedaan total aktiva yang terlalu ekstrim antara perusahaan satu dengan lainnya (Dela dan Sunaryo, 2010).

SIZE $=$ Ln (Total Aktiva)

Variabel terikat $(\mathrm{Y})$ adalah manajemen laba, yaitu intervensi manajer terhadap proses pelaporan keuangan eksternal dengan sengaja untuk memperoleh beberapa keuntungan, tanpa mengakibatkan kenaikan atau penurunan profitabilitas ekonomi jangka panjang. Manajemen laba, dihitung dengan Modified Jones Model, dengan rumus:

$\mathrm{TACC}_{\text {it }}=\mathrm{NI}_{\mathrm{it}}-\mathrm{OCF}_{\mathrm{it}}$

Dimana:

$\mathrm{TACC}_{\mathrm{it}}=$ Total akrual perusahaan i pada tahun $\mathrm{t}$

$\mathrm{NI}_{\mathrm{it}}=$ Net income (laba bersih) perusahaan i pada periode $\mathrm{t}$

$\mathrm{OCF}_{\mathrm{it}}=$ Operating cash flow perusahaan i pada periode $\mathrm{t}$

$\mathrm{TACC}_{\mathrm{it}} / \mathrm{TA}_{\mathrm{it}-1}=\beta_{1}\left(1 / \mathrm{TA}_{\mathrm{it}-1}\right)+\beta_{2}\left(\Delta \mathrm{Rec}_{\mathrm{it}} / \mathrm{TA}_{\mathrm{it}-1}\right)+\beta_{3}\left(\mathrm{PPE}_{\mathrm{it}} / \mathrm{TA}_{\mathrm{it}-1}\right)$

Untuk menilai praktik manajemen laba, maka nilai total akrual dibedakan menjadi discretionary accrual dan non-discretionary accrual. Nondiscretionary accrul dihitung dengan rumus:

$\mathrm{NDACC}_{\mathrm{it}}=\beta_{1}\left(1 / \mathrm{TA}_{\mathrm{it}-1}\right)+\beta_{2}\left(\Delta \mathrm{REV}_{\mathrm{it}}-\Delta \mathrm{REC}_{\mathrm{it}} / \mathrm{TA}_{\mathrm{it}-1}\right)+\beta_{3}\left(\mathrm{PPE}_{\mathrm{it}} / \mathrm{TA}_{\mathrm{it}-1}\right)$

Keterangan:

NDACCit $=$ Non discretionary accrual perusahaan i pada tahun $\mathrm{t}$

$\mathrm{TA}_{\mathrm{it}-1}=$ Total aktiva perusahaan i pada tahun $\mathrm{t}-1$

$\triangle \mathrm{REV}_{\mathrm{it}}=$ Perubahan pendapatan perusahaan i pada tahun ke $\mathrm{t}$

$\triangle \mathrm{REC}_{\mathrm{it}}=$ Perubahan piutang perusahaan i pada tahun ke $\mathrm{t}$

$\mathrm{PPE}_{\mathrm{it}}=$ Aktiva tetap perusahaan i pada tahun $\mathrm{t}$

$\beta \mathrm{i}=$ Koefisien regresi

Discretionary accrual (DA) dihitung dengan rumus:

$\mathrm{DACC}_{\mathrm{it}}=\left(\mathrm{TACC}_{\mathrm{it}} / \mathrm{TA}_{\mathrm{it}-1}\right)-\mathrm{NDACC}_{\mathrm{it}}$

Keterangan:

$\mathrm{DACC}_{\mathrm{it}}=$ Discretionary Accruals perusahaan i pada tahun $\mathrm{t}$

$\mathrm{NDACC}_{\mathrm{it}}=$ Non discretionary accrual perusahaan i pada tahun $\mathrm{t}$

$\mathrm{TACC}_{\mathrm{it}}=$ Total akrual perusahaan i pada tahun $\mathrm{t}$

Dari hasil perhitungan diketahui jika tidak terjadi praktik manajemen laba, maka besarnya DACC $=0$. Jadi nilai discretionary accrual $\left(\mathrm{DACC}_{\mathrm{it}}\right)$ mengindikasikan tingkat akrual hasil praktik manajemen laba. Rekayasa menaikkan laba (income increasing discretionary accrual) ditunjukkan dengan nilai DACC yang positif, dan rekayasa menurunkan laba (income descreasing discretionary accrual) diindikasikan dengan nilai DACC yang negatif.

Skala pengukuran variabel bebas dan variabel terikat adalah skala rasio. 


\section{Teknik Pengumpulan Data}

Teknik pengumpulan data yang digunakan dalam penelitian ini adalah teknik dokumentasi. Teknik dokumentasi dilakukan dengan mengumpulkan data-data yang sudah diolah sebelumnya dari objek penelitian berupa data laporan keuangan perusahaan manufaktur yang terdaftar di Bursa Efek Indonesia tahun 2011-2013. Data ini diperoleh dari website IDX (Indonesian Stock Exchange) atau www.idx.co.id.

\section{HASIL PENELITIAN DAN PEMBAHASAN}

Asimetri informasi menunjukkan keadaan yang muncul ketika manajer lebih mengetahui informasi internal dan prospek bisnis perusahaan dibandingkan dengan pihak-pihak yang berkepentingan terhadap perusahaan. Asimetri informasi dihitung dengan menggunakan relative bid-ask spread.

Leverage mengukur sejauh besar aktiva perusahaan didanai dengan hutang. Leverage diukur dari debt ratio, yaitu total hutang dibagi total aktiva.

Ukuran perusahaan menunjukkan besar kecilnya skala perusahaan yang ditunjukkan oleh total aktivanya. Ukuran perusahaan diukur dari total aktiva yang ditransformasikan dalam bentuk logaritma natual (ln) untuk memperhalus data.

\section{Hasil Uji Asumsi Klasik}

Berdasarkan hasil pengujian dengan menggunakan program SPSS Versi 20, diperoleh hasil uji asumsi klasik, sebagai berikut:

1. Hasil uji normalitas

Uji Kolmogorov Smirnov merupakan pengujian normalitas.

Tabel Hasil Uji Normalitas

\begin{tabular}{|ll|r|r|r|r|}
\hline & & \multicolumn{1}{|c|}{$\mathrm{X} 1$} & \multicolumn{1}{|c|}{$\mathrm{X} 2$} & \multicolumn{1}{c|}{$\mathrm{X} 3$} & \multicolumn{1}{c|}{$\mathrm{Y}$} \\
\hline$N$ & 150 & 150 & 150 & 150 \\
Normal & Mean & 69,23 & 47,77 & 14,78 & 0,21 \\
Parameters $(a, b)$ & Std. Deviation & 35,39 & 24,17 & 1,53 & 0,10 \\
Most Extreme & Absolute & 0,149 & 0,123 & 0,068 & 0,126 \\
Differences & Positive & 0,149 & 0,123 & 0,068 & 0,126 \\
& Negative & $-0,074$ & $-0,076$ & $-0,039$ & $-0,121$ \\
\multicolumn{2}{|c|}{ Kolmogorov-Smirnov Z } & 1,252 & 1,503 & 0,837 & 1,049 \\
Asymp. Sig. (2-tailed) & 0,063 & 0,080 & 0,485 & 0,057 \\
\hline
\end{tabular}

Sumber data : Olahan SPSS 
Dari tabel dapat dijelaskan hasil uji normalitas sebagai berikut:

a. Nilai Kolmogorov-Sminorv (K-S) sebesar 1,252 dengan tingkat signifikan $0,063>0,05$. Artinya, variabel asimetri informasi terdistribusi normal.

b. Nilai Kolmogorov-Sminorv (K-S) sebesar 1,503 dengan tingkat signifikan 0,080 >0,05. Artinya, variabel leverage terdistribusi normal.

c. Nilai Kolmogorov-Sminorv (K-S) sebesar 0,837 dengan tingkat signifikan $0,485>0,05$. Artinya, variabel ukuran perusahaan terdistribusi normal.

d. Nilai Kolmogorov-Sminorv (K-S) sebesar 1,049 dengan tingkat signifikan $0,057>0,05$. Artinya, variabel praktik manajemen laba terdistribusi normal.

\section{Hasil Uji Multikolinieritas}

Uji multikolinieritas bertujuan untuk menguji apakah model regresi ditemukan adanya korelasi antar variabel bebas. Uji multikolinieritas diukur dari Variance Inflating Factor (VIF). Kriteria pengambilan keputusan:

- Jika nilai VIF $>10$, berarti mengalami multikolinieritas

- Jika nilai VIF < 10, berati tidak mengalami multikolinieritas.

Berdasarkan print output SPSS versi 20, diperoleh hasil uji multikolinieritas seperti pada tabel berikut:

Tabel Hasil Uji Multikolinieritas

\begin{tabular}{|c|c|c|}
\hline \multirow{2}{*}{ Model } & \multicolumn{2}{|c|}{ Collinearity Statistics } \\
\cline { 2 - 3 } & Tolerance & VIF \\
\hline X1 & 0,818 & 1,223 \\
X2 & 0,824 & 1,214 \\
X3 & 0,955 & 1,047 \\
\hline
\end{tabular}

Sumber data : Olahan SPSS

Tabel Hasil Uji Autokorelasi

\begin{tabular}{|l|r|}
\hline \multicolumn{1}{|c|}{ Model } & Durbin-Watson \\
\hline 1 & 1,495 \\
\hline
\end{tabular}

Dari tabel di atas, diketahui nilai DW sebesar 1,495. Kriteria pengujian adalah $\mathrm{d}_{\mathrm{U}} \leq \mathrm{DW} \leq 4,00-\mathrm{d}_{\mathrm{U}}$. Nilai $\mathrm{d}_{\mathrm{U}}$ sebesar 1,67, maka 1,67 $\leq$ $1,495 \leq 2,505$. Artinya, tidak terdapat autokorelasi antara asimetri informasi, leverage dengan ukuran perusahaan. 


\subsection{Pengujian Hipotesis}

Tabel Coefficients $(a)$

\begin{tabular}{|ll|r|r|r|r|r|}
\hline \multirow{2}{*}{ Model } & \multicolumn{2}{|c|}{$\begin{array}{c}\text { Unstandardized } \\
\text { Coefficients }\end{array}$} & $\begin{array}{c}\text { Standardized } \\
\text { Coefficients }\end{array}$ & \multirow{2}{*}{$t$} & \multirow{2}{*}{ Sig. } \\
\cline { 2 - 5 } & \multicolumn{1}{|c|}{$B$} & Std. Error & Beta & & \\
\hline 1 & (Constant) & $-0,101$ & 0,068 & & $-1,471$ & 0,143 \\
& X1 & 0,001 & 0,000 & 0,250 & 3,377 & 0,001 \\
& X2 & 0,002 & 0,000 & 0,403 & 5,457 & 0,000 \\
X3 & 0,013 & 0,004 & 0,193 & 2,808 & 0,006 \\
\hline
\end{tabular}

Sumber data : Olahan SPSS

Kriteria pengambilan keputusan:

a. Jika $t_{\text {hitung }}\left(3,377 ; 5,457\right.$ dan 2,808) $>t_{\text {tabel }(1,976)}$ atau jika signifikan $<$ 0,05 , maka $\mathrm{H}_{0}$ ditolak

b. Jika $t_{\text {hitung }}\left(3,377 ; 5,457\right.$ dan 2,808) $<t_{\text {tabel }(1,976)}$, atau jika signifikan $>$ 0,05 , maka $\mathrm{H}_{0}$ diterima

Berdasarkan hasil pengujian dengan menggunakan program SPSS versi 20, diperoleh hasil uji $\mathrm{F}$, sebagai berikut:

Tabel Anova $(b)$

\begin{tabular}{|ll|r|r|r|r|c|}
\hline & Model & $\begin{array}{c}\text { Sum of } \\
\text { Squares }\end{array}$ & \multicolumn{1}{c|}{$d f$} & $\begin{array}{c}\text { Mean } \\
\text { Square }\end{array}$ & \multicolumn{1}{c|}{$F$} & Sig. \\
\hline 1 & Regression & 0,509 & 3 & 0,170 & 25,514 & $0,000(\mathrm{a})$ \\
& Residual & 0,972 & 146 & 0,007 & & \\
& Total & 1,481 & 149 & & & \\
\hline
\end{tabular}

a Predictors: (Constant), X3, X2, X1

b Dependent Variable: Y

Kriteria pengambilan keputusan:

c. Jika $F_{\text {hitung }}(25,514)>F_{\text {tabel (1.976) }}$ atau jika signifikan $<0,05$, maka $\mathrm{H}_{0}$ ditolak

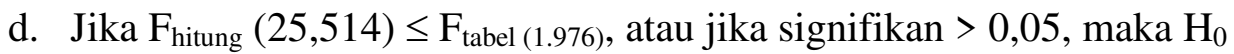
diterima

\section{Pembahasan}

Berdasarkan hasil pengujian dengan menggunakan bantuan program SPSS versi 20, diperoleh nilai koefisien korelasi (R) dan nilai koefisien determinan ( $R$-Square) sebagai berikut: 
Tabel Model Summary $(b)$

\begin{tabular}{|l|c|r|r|c|}
\hline Model & $R$ & $R$ Square & $\begin{array}{c}\text { Adjusted } R \\
\text { Square }\end{array}$ & $\begin{array}{c}\text { Std. Error of the } \\
\text { Estimate }\end{array}$ \\
\hline 1 & $0,586(\mathrm{a})$ & 0,344 & 0,330 & 0,08158 \\
\hline
\end{tabular}

a Predictors: (Constant), X3, X2, X1

b Dependent Variable: Y

Sumber data : Olahan SPSS

Berdasarkan tabel 4.6, diperoleh persamaan regresi linear berganda adalah $\mathrm{Y}=-0,101+0,001 \mathrm{X}_{1}+0,002 \mathrm{X}_{2}+0,013 \mathrm{X}_{3}$. Artinya, asimetri informasi, leverage dan ukuran perusahaan berpengaruh positif terhadap praktik manajemen laba pada perusahaan manufaktur yang terdaftar di Bursa Efek Indonesia. Hal ini dapat dilihat dari nilai koefisien regresinya.

\section{Pengaruh Asimetri Informasi Terhadap Praktik Manajemen Laba}

Dilihat dari nilai koefisien regresinya, diketahui bahwa pengaruh asimetri informasi terhadap praktik manajemen laba sebesar 0,001. Artinya, jika asimetri informasi berubah, maka praktik manajemen laba akan berubah sebesar 0,001 . Dengan demikian, terdapat pengaruh positif antara asimetri informasi terhadap praktik manajemen laba. Hal ini didukung dengan hasil uji $t$, dimana nilai $t_{\text {hitung }}(3,377)>t_{\text {tabel }}(1,976)$ dengan tingkat signifikansi $0,001<0,05$, sehingga $\mathrm{H}_{0}$ ditolak. Artinya, asimetri informasi berpengaruh positif signifikan secara parsial terhadap praktik manajemen laba pada perusahaan manufaktur yang terdaftar di Bursa Efek Indonesia.

\section{Pengaruh Leverage Terhadap Praktik Manajemen Laba}

Leverage mengukur seberapa besar perusahaan dibiayai dengan hutang. Penggunaan hutang yang terlalu tinggi akan membahayakan perusahaan, karena perusahaan akan masuk dalam kategori extreme leverage (hutang ekstrim) yaitu perusahaan terjebak dalam tingkat hutang yang tinggi, dan sulit untuk melepaskan beban tetap berupa bunga pinjaman pada saat keadaan perekonomian buruk. Besar kecilnya rasio leverage sangat tergantung dari pinjaman perusahaan dan ekuitas pemilik perusahaan. Pada saat rasio leverage tinggi, berarti perusahaan cenderung melakukan praktik manajemen laba karena perusahaan tidak dapat memenuhi kewajibannya pada saat jatuh tempo. Leverage yang tinggi berpengaruh positif terhadap praktik manajemen laba.

Dilihat dari nilai koefisien regresinya, diketahui bahwa pengaruh leverage terhadap praktik manajemen laba sebesar 0,002. Artinya, jika 
leverage berubah, maka praktik manajemen laba akan berubah sebesar 0,002. Dengan demikian, terdapat pengaruh positif antara leverage terhadap praktik manajemen laba. Hal ini didukung dengan hasil uji t, dimana nilai $t_{\text {hitung }}(5,457)>t_{\text {tabel }}(1,976)$ dengan tingkat signifikansi 0,000 $<0,05$, sehingga $\mathrm{H}_{0}$ ditolak. Artinya, leverage berpengaruh positif signifikan secara parsial terhadap praktik manajemen laba pada perusahaan manufaktur yang terdaftar di Bursa Efek Indonesia. Hasil penelitian ini mendukung penelitian Azlina (2010) yang menyimpulkan bahwa leverage berpengaruh positif dan signifikan terhadap manajemen laba pada perusahaan perbankan.

\section{Pengaruh Ukuran Perusahaan Terhadap Praktik Manajemen Laba}

Ukuran perusahaan yang diukur dari total asset yang dimiliki perusahaan. Ukuran perusahaan berpengaruh positif terhadap manajemen laba, karena perusahaan besar cenderung melakukan praktik manajemen laba untuk memenuhi ekspektasi dari investor atau pemegang saham.

Dilihat dari nilai koefisien regresinya, diketahui bahwa pengaruh ukuran perusahaan terhadap praktik manajemen laba sebesar 0,013. Artinya, jika ukuran perusahaan berubah, maka praktik manajemen laba akan berubah sebesar 0,013. Dengan demikian, terdapat pengaruh positif antara ukuran perusahaan terhadap praktik manajemen laba. Hal ini didukung dengan hasil uji $t$, dimana nilai $t_{\text {hitung }}(2,808)>t_{\text {tabel }}(1,976)$ dengan tingkat signifikansi $0,006<0,05$, sehingga $\mathrm{H}_{0}$ ditolak. Artinya, ukuran perusahaan berpengaruh positif signifikan secara parsial terhadap praktik manajemen laba pada perusahaan manufaktur yang terdaftar di Bursa Efek Indonesia.

\section{KESIMPULAN DAN SARAN}

\section{Kesimpulan}

Berdasarkan hasil pembahasan disimpulkan bahwa:

1. Hasil uji asumsi klasik diketahui bahwa variabel asimetri informasi dan leverage terdistribusi normal, sedangkan variabel ukuran perusahaan dan praktik manajemen laba terdistribusi tidak normal. Asimetri informasi, leverage, ukuran perusahaan tidak mengalami multikolinieritas, tidak terdapat autokorelasi dan juga tidak terjadi heteroskedastisitas. Dengan demikian, uji hipotesis dapat diolah lebih lanjut.

2. Nilai koefisien korelasi (R) sebesar 0,586. Artinya, asimetri informasi, leverage dan ukuran perusahaan mempunyai hubungan positif terhadap 
praktik manajemen laba pada perusahaan manufaktur yang terdaftar di Bursa Efek Indonesia. Nilai koefisien determinan ( $R$ Square) sebesar 0,344 . Artinya, praktik manajemen laba dapat dijelaskan oleh asimetri informasi, leverage dan ukuran perusahaan $34,4 \%$ sedangkan $65,6 \%$ dijelaskan oleh faktor lain.

3. Dari hasil uji $t$, diketahui nilai $t_{\text {hitung }}(3,377)>t_{\text {tabel }}(1,976)$ dengan tingkat signifikansi $0,001<0,05$, sehingga $\mathrm{H}_{0}$ ditolak. Artinya, asimetri informasi berpengaruh positif signifikan secara parsial terhadap praktik manajemen laba pada perusahaan manufaktur yang terdaftar di Bursa Efek Indonesia, sehingga hipotesis I diterima.

4. Dari hasil uji $t$, diketahui nilai $t_{\text {hitung }}(5,457)>t_{\text {tabel }}(1,976)$ dengan tingkat signifikansi $0,000<0,05$, sehingga $\mathrm{H}_{0}$ ditolak. Artinya, leverage berpengaruh positif signifikan secara parsial terhadap praktik manajemen laba pada perusahaan manufaktur yang terdaftar di Bursa Efek Indonesia, sehingga hipotesis II diterima.

5. Dari hasil uji $t$, diketahui nilai $t_{\text {hitung }}(2,808)>t_{\text {tabel }}(1,976)$ dengan tingkat signifikansi $0,006<0,05$, sehingga $\mathrm{H}_{0}$ ditolak. Artinya, ukuran perusahaan berpengaruh positif signifikan secara parsial terhadap praktik manajemen laba pada perusahaan manufaktur yang terdaftar di Bursa Efek Indonesia, sehingga hipotesis III diterima.

6. Dari hasil uji $F$, diketahui nilai $F_{\text {hitung }}(25,514)>F_{\text {tabel }}(2,67)$ dengan tingkat signifikansi $0,000<0,05$, sehingga $\mathrm{H}_{0}$ ditolak. Artinya, asimetri informasi, leverage dan ukuran perusahaan berpengaruh positif signifikan secara simultan terhadap praktik manajemen laba pada perusahaan manufaktur yang terdaftar di Bursa Efek Indonesia.

7. Persamaan regresi linear berganda adalah $\mathrm{Y}=-0,101+0,001 \mathrm{X}_{1}+$ $0,002 X_{2}+0,013 X_{3}$. Artinya, asimetri informasi, leverage dan ukuran perusahaan berpengaruh positif terhadap praktik manajemen laba pada perusahaan manufaktur yang terdaftar di Bursa Efek Indonesia. Hal ini dapat dilihat dari nilai koefisien regresinya.

\section{Saran}

Saran yang diberikan kepada peneliti selanjutnya adalah untuk mendapatkan hasil analisis yang lebih akurat, sebaiknya peneliti lain menambah sampel atau variabel penelitian. 


\section{DAFTAR PUSTAKA}

Agusti, Restu dan Pramesti, Tyas. 2013. Pengaruh Asimetri Informasi, Ukuran Perusahaan, Kepemilikan Manajerial Terhadap Manajemen Laba. Artikel: Dosen Jurusan Akuntansi Fakultas Ekonomi Universitas Riau.

Azlina, Nur. 2010. Analisis Faktor yang Mempengaruhi Manajemen Laba (Studi pada Perusahaan Perbankan Yang Terdaftar di BEI). Jurnal Riset Akuntansi Indonesia Vol.11, No.1

Brigham, Eugene G., dan Joel F. Houston, 2006. Manajemen Keuangan. Buku Satu, Alih Bahasa: Ali Akbar Yulianto, Jakarta: Salemba Empat.

Dela, Feramon dan Sunaryo, Kunti. 2010. Pengaruh Asimetri Informasi, Ukuran Perusahaan dan Kepemilikan Manajerial Terhadap Praktik Manajemen Laba, Jurnal: Kajian Akuntansi, Volume 5, Nomor 1, Juni 2010, ISSN 1907 - 1442.

Ghozali, Imam, 2005. Analisis Multivarice dengan Program SPSS, Edisi Ketiga, Badan Penerbit Universitas Diponegoro.

Fahmi, Irham. 2013. Pengantar Manajemen Keuangan. Edisi Pertama, Cetakan Pertama, Bandung: Alfabeta.

Harahap, Sofyan Syafri. 2007. Teori Akuntansi, Edisi Revisi, Jakarta: Raja Grafindo Persada.

Kasmir, 2008. Analisis Laporan Keuangan. Edisi Pertama, Cetakan Pertama, Jakarta: PT. Raja Grafindo Persada.

Muliati. 2011. Pengaruh Asimetri Informasi dan Ukuran Perusahaan Terhadap Manajemen Laba pada Perusahaan Perbankan yang Terdaftar di Bursa Efek Indonesia, Tesis: Program Pascasarjana Universitas Udayana Denpasar.

Nasution, Marihot dan Setiawan. 2007. Pengaruh Corporate Terhadap Manajemen Laba di Industri Perbankan. Simposium Nasional Akuntansi X.

Rahmawati, Yacob Suparto dan Nurul Qomariah, 2006. Pengaruh Asimetri Informasi Terhadap Praktik Manajemen Laba Pada Perusahaan Perbankan yang Terdaftar di Bursa Efek Jakarta, Simposium Nasional Akuntansi IX. Padang.

Restuwulan. 2013. Pengaruh Asimetri Informasi, Ukuran Perusahaan Terhadap Manajemen Laba Pada Perusahaan Manufaktur sektor Food and Beverages. Jurnal Riset Akuntansi, Simposium Nasional V.

Sawir, Agnes, 2005. Analisis Kinerja Keuangan dan Perencanaan Keuangan Perusahaan. Jakarta: PT. Gramedia Pustama Utama. 
Siregar, Silvia. 2002. Pengaruh Pertumbuhan Hutang dan Asimetri Informasi Terhadap Penilaian Pasar Atas Discretionary Accrual, Jurnal Riset Akuntansi Indonesia Vol. 9, No. 3, hal 307-326.

Scott, William R. 2009. Financial Accounting Theory. Second Edition. Ontario: Prentice Hall Canana Inc.

Sjahrial, Dermawan. 2007. Manajemen Keuangan Lanjutan, Edisi Pertama. Jakarta: Mitra Wacana Media.

Sujarweni, V. Wiratna. 2014. SPSS Untuk Penelitian, Cetakan Pertama. Yogyakarta: Penerbit Pustaka Baru Pers

Sulistyanto, Sri. 2008. Manajemen Laba: Teori dan Model Empiris. Jakarta: PT.Gramedia Widiasarana Indonesia.

Sugiyono, 2008. Metode Penelitian Bisnis, Cetakan Keduabelas, Bandung: Alfabeta.

Sunyoto, Danang. 2013. Analisis Laporan Keuangan Untuk Bisnis, Cetakan Pertama, Yogyakarta: Caps.

Wardani, Dini Tri dan Warsoda. 2011. Pengaruh Asimetri Informasi, Struktur Kepemilikan Manajerial dan Leverage Terhadap Praktik Manajemen Laba Dalam Industri Perbankan di Indonesia, Jurnal: Proceeding PESAT, Vol. 4 Oktober 2011, ISSN: 1858-2559.

Wiryadi, Arri dan Nurzi Sebrina. 2012. Pengaruh Asimetri Informasi, Kualitas Audit, dan Struktur Kepemilikan Terhadap Manajemen Laba. Jurnal: WRA, Vol. 1, No. 2, Oktober 2013.

www.idx.co.id. 